\title{
GIS and Remote Sensing Applications in Wetland Mapping and Monitoring
}

\author{
Qiusheng Wu
}

Department of Geography, Binghamton University, State University of New York, Binghamton, NY 13902, USA;

Correspondence: wqs@binghamton.edu; Tel.: +1-607-777-3145

\begin{abstract}
Wetlands are recognized as one of the world's most valuable natural resources. With the increasing world population, human demands on wetland resources for agricultural expansion and urban development continue to increase. In addition, global climate change has pronounced impacts on wetland ecosystems through alterations in hydrological regimes. To better manage and conserve wetland resources, we need to know the distribution and extent of wetlands and monitor their dynamic changes. Wetland maps and inventories can provide crucial information for wetland conservation, restoration, and management. Geographic Information System (GIS) and remote sensing technologies have proven to be useful for mapping and monitoring wetland resources. Recent advances in geospatial technologies have greatly increased the availability of remotely sensed imagery with better and finer spatial, temporal, and spectral resolution. This chapter presents an introduction to the uses of GIS and remote sensing technologies for wetland mapping and monitoring. A case study is presented to demonstrate the use of high-resolution light detection and ranging (LiDAR) data and aerial photographs for mapping prairie potholes and surface hydrologic flow pathways.
\end{abstract}

Keywords: GIS; image classification; LiDAR; remote sensing; wetland indicator; global wetland inventory; wetland mapping

\section{Acronyms and Definitions}

$\begin{array}{ll}\text { CCI } & \text { Climate Change Initiative } \\ \text { CIFOR } & \text { Center for International Forestry Research } \\ \text { DEM } & \text { Digital Elevation Model } \\ \text { ELUs } & \text { Ecological Land Units } \\ \text { ETM } & \text { Enhanced Thematic Mapper } \\ \text { ESA } & \text { European Space Agency } \\ \text { ESRI } & \text { Environmental Systems Research Institute } \\ \text { FAO } & \text { Food and Agriculture Organization of the United Nations } \\ \text { GIEMS } & \text { Global Inundation Extent from Multi-Satellites } \\ \text { GIS } & \text { Geographical Information Systems } \\ \text { GLCF } & \text { Global Land Cover Facility } \\ \text { GLWD } & \text { Global Lakes and Wetlands Database } \\ \text { LiDAR } & \text { Light Detection and Ranging } \\ \text { MODIS } & \text { Moderate Resolution Imaging Spectroradiometer } \\ \text { NAIP } & \text { National Agriculture Imagery Program } \\ \text { NDVI } & \text { Normalized Difference Vegetation Index } \\ \text { NDWI } & \text { Normalized Difference Water Index } \\ \text { NIR } & \text { Near Infrared }\end{array}$




$\begin{array}{ll}\text { NRCS } & \text { Natural Resources Conservation Service } \\ \text { NWI } & \text { National Wetlands Inventory } \\ \text { OBIA } & \text { Object-based Image Analysis } \\ \text { PPR } & \text { Prairie Pothole Region } \\ \text { SAR } & \text { Synthetic Aperture Radar } \\ \text { TM } & \text { Thematic Mapper } \\ \text { UAS } & \text { Unmanned Aerial Systems } \\ \text { UNEP } & \text { United Nations Environment Program } \\ \text { UNESCO } & \text { United Nations Educational, Scientific and Cultural Organization } \\ \text { USDA } & \text { United States Department of Agriculture } \\ \text { USGS } & \text { United States Geological Survey } \\ \text { WCMC } & \text { World Conservation Monitoring Centre }\end{array}$

\section{Introduction}

Wetlands are recognized as one of the world's most valuable natural resources (Burton and Tiner 2009; Tiner 2015b). Wetlands provide numerous ecological and socio-economic benefits, such as providing critical habitats for fish, wildlife, and plant communities, storing floodwater and reducing peak runoff, recharging groundwater, filtering impurities in water, acting as nutrient and sediment sinks, protecting shorelines from erosion, and providing a range of recreational opportunities (e.g., boating, fishing, hunting). With the increasing world population, human demands on wetland resources for agricultural expansion and urban development continue to increase (Mitsch and Gosselink 2000; Zedler and Kercher 2005). In addition, global climate change has pronounced impacts on wetland ecosystems through alternations in hydrological regimes (Erwin 2009). It was estimated that $64 \%$ of the world's wetlands have disappeared since 1900 (Ramsar Convention 2009). The rate of wetland loss varies considerably from country to country. In a report to the United States Congress on the status of wetland resources, Dahl (1990) estimated that the Conterminous United States lost an estimated $53 \%$ of their original wetlands over a period of 200 years between the 1780 s and the 1980s. Similarly, China suffered a 33\% wetland loss in just 30 years from 1978 to 2008 (Niu et al. 2012).

To better manage and conserve wetland resources, we need to know the distribution and extent of wetlands and monitor their dynamic changes. However, there is no single, indisputable, universally accepted definition of wetlands due to the diversity of wetlands (Cowardin et al. 1979; Tiner 2009b), making it difficult to determine the global wetland extent. The term "wetlands" covers a wide variety of aquatic habitats, including marshes, swamps, bogs, fens, peatlands, prairie potholes, vernal pools, and aquatic beds, among others. In general, wetlands are transitional habitats situated between wet (e.g., lakes, rivers, streams, estuaries) and dry (upland) environments. Thus, the demarcation of a wetland lies along a continuum of water gradient and is somewhat arbitrary. Some wetland definitions include open-water habitats (e.g., lakes, rivers, streams) as wetlands, while others exclude permanent deepwater and focus more on shallow water habitats. For example, in the national wetland classification system adopted in the United States, permanently flooded freshwater aquatic systems deeper than $2 \mathrm{~m}$ are generally classified as deepwater habitats and are not considered as wetlands (Cowardin et al. 1979). In contrast, under the Ramsar international wetland conservation treaty, wetlands are defined as areas of marsh, fen, peatland or water, whether natural or artificial, permanent or temporary, with water that is static or flowing, fresh, 
brackish or salt, including areas of marine water the depth of which at low tide does not exceed six metres (Ramsar Convention Secretariat 2016). In the Canadian wetland classification system, a wetland is defined as land that is saturated with water long enough to promote wetland or aquatic processes as indicated by poorly drained soils, hydrophytic vegetation and various kinds of biological activity which are adapted to a wet environment (National Wetlands Working Group 1997). Although the technical definition of wetlands adopted by different countries varies to some degree, they still have much in common. The presence of water, either permanent or temporary, must be long enough to support animal species, plant communities, soil development, and the variety of functions attributed to these natural resources (Tiner 2015b).

Geographic Information System (GIS) and remote sensing technologies have proven to be useful for mapping and monitoring wetland resources (Adam et al. 2010; Lang et al. 2015; Lyon et al. 2001; Ozesmi and Bauer 2002; Rebelo et al. 2009; Sader et al. 1995). Wetland maps and inventories provide crucial information for wetland conservation, restoration, and management. Since the first multispectral satellite data (i.e., Landsat MSS) became publicly available in the 1970s, significant efforts have been made to develop remote sensing technology. The technological advances have led to the increasing availability of remotely sensed imagery with better and finer spatial, temporal, and spectral resolution. In the meantime, image analysis and processing methods have been improving, which enables us to map wetlands and monitor changes with unprecedented accuracy. In particular, the availability of high-resolution light detection and ranging (LiDAR), synthetic aperture radar (SAR), hyperspectral, and multispectral data, and the introduction of multi-sensor and multiscale data fusion techniques hold great potential for improving large-scale wetland mapping and monitoring (Lang et al. 2015). This chapter presents an introduction to the uses of GIS and remote sensing technologies for wetland mapping and monitoring. A case study will be presented to demonstrate the use of high-resolution light detection and ranging (LiDAR) data and aerial photographs for mapping prairie potholes and surface hydrologic flow pathways.

\section{Wetland Indicators}

As noted above, there is no universally accepted definition of wetlands due to the diversity of wetland types. Wetlands can occur in a variety of landscape, hydrologic, and climatic settings. They differ in size, shape, plant, soil, and hydrologic conditions. Despite these differences, wetlands can still be categorized into certain types based on their common characteristics. Some wetland types are easier to identify in the field than others due to their distinctive features. Although identifying wetlands in the field is indispensable to wetland inventory and field verification, it is labor-intensive, time-consuming, and impractical for surveying a large area. GIS and remote sensing techniques can facilitate wetland identification and delineation by analyzing a combination of wetland indicators such as hydrology, vegetation, soil types, and topographic position. These wetland indicators can be represented as various wetland indicator layers in a GIS environment, which can be overlaid or integrated to identify areas where there is a high probability that wetlands may be present (i.e., potential wetlands).

\subsection{Hydrology}


Among the many wetland indicators, hydrology is probably the most important factor that affects the formation and functions of a wetland as it influences plant communities, animal species, soil properties, and human use. Lands must remain 'wet' for a long period of time during the growing season in order to be designated as wetlands. The prolonged wetness of wetlands results from water received from various sources, including precipitation, snowmelt, surface water runoff, groundwater discharge, among others. Based on the frequency and duration of inundation or soil saturation, wetlands can generally be classified as ephemeral, temporary, seasonal, semipermanent, and permanent wetlands. In the United States, the minimum wetness for a federally regulated wetland is defined by saturation within $30 \mathrm{~cm}$ of the surface for at least two weeks during the growing season in most years (Tiner 2015b). In general, wetlands with a high wetness are relatively easier to identify than dried wetlands through remote sensing. Apart from cloud shadows, a dark tone in multispectral remote sensing imagery is often indicative of water or high soil moisture areas, where wetlands are likely to occur. The Normalized Difference Water Index (NDWI) is a commonly used index to detect and delineate water-like features and high soil moisture areas (McFeeters 1996). The formula for calculating NDWI is:

$$
N D W I=\frac{(\text { GREEN }-N I R)}{(\text { GREEN }+N I R)}
$$

where NIR and GREEN represent the spectral reflectance values acquired in the near-infrared and green portion of the electromagnetic spectrum, respectively. Theoretically, NDWI values range from -1 to +1 . An NDWI value that is negative or close to zero means no water whereas an NDWI value close to +1 indicates the highest wetness. In addition to multispectral imagery, high-resolution LiDAR and SAR data are increasingly being used to map surface water and wetlands (Brian 2015; Huang et al. 2011b; Lang and McCarty 2009; Wu and Lane 2016).

\subsection{Hydrophytic Vegetation}

The nature of plants colonizing wetlands is considered one of the most distinctive features of wetlands, as vegetation life form and patterns, if present, can be easily observed and recognized (Tiner 2009a). These plants are called hydrophytic vegetation. In the United States, it was reported that the national list of wetland plants contains nearly 6700 species (Tiner 1991). These species have adapted to the frequent and prolonged flooding events that occur in wetlands. Remotely sensed data are frequently used to identify specific plant species or vegetation types indicative of wetlands. The most well-known and commonly used index to detect green vegetation from multispectral remote sensing data is the Normalized Difference Vegetation Index (NDVI) (Tucker 1979). The formula for calculating NDVI is:

$$
N D V I=\frac{(N I R-R E D)}{(N I R+R E D)}
$$

where NIR and RED represent the spectral reflectance values acquired in the near-infrared and red portion of the electromagnetic spectrum, respectively. Theoretically, NDVI values range from -1 to +1 . An NDVI value that is negative or close to zero means no vegetation whereas an NDVI value close to +1 indicates the highest concentration of green vegetation.

\subsection{Hydric Soils}

Hydric soils are soils that are saturated, ponded or flooded long enough during the growing season to promote the development of anaerobic conditions in the upper horizons. These conditions are favorable environmental conditions for supporting the growth and 
reproduction of hydrophytic vegetations. Most wetlands have hydric soils and hydrophytic vegetations present, however, there are also some non-vegetated wetlands (e.g., mudflats). The U.S. Department of Agriculture (USDA) Natural Resources Conservation Service (NRCS) developed a national list of hydric soils which are updated periodically (USDA-NRCS 2010). Currently, there are approximately 2000 hydric soil types in this national list (USDA-NRCS 2016a). Each hydric soil type is a unique combination of physical, chemical, and moisture properties. The USDA-NRCS also developed a GIS database called Soil Survey Geographic Database (SSURGO), which contains soils information collected over the course of a century (USDA-NRCS 2016b). The SSURGO database consists of spatial data (map unit polygons) and tabular data (attribute tables). The map unit polygons (MUPLOYGON) delineate the extent of different soils. The attribute table (muaggatt) contains the hydric soil information, which can be joined to the map unit polygons through the common MUKEY column. In the muaggatt attribute table, there is a field called hydclprs (Alias: Hydric Classification - Presence), which indicates the proportion of the map unit that is hydric. Map units with a higher proportion of hydric soils are more likely to contain wetlands. In other words, wetlands are less likely to occur on non-hydric soils. However, the absence of hydric soil does not mean that the area is always without wetlands, since SSURGO data have a limited map scale between 1:24K $1: 12 \mathrm{~K}$. Therefore, it is recommended that the hydric soil indicator be used in conjunction with hydrology and vegetation indicators to identify areas with a high probability of wetland occurrence.

\subsection{Topographic Position}

In addition to the three key wetland indicators (hydrology, hydrophytic vegetation, and hydric soil) mentioned above, topographic position can be used as a supplementary indicator of wetland occurrence. Digital elevation models (DEMs) are commonly used to derive primary topographic metrics (e.g., slope, aspect, and curvature) and secondary topographic metrics, which are computed from two or more primary metrics. One of the most widely used secondary topographic metrics is the Topographic Wetness Index (TWI), which quantifies the tendency of a grid cell to receive and accumulate water (Sörensen et al. 2006). The TWI is defined as:

$$
T W I=\ln \left(\frac{A}{\tan (\beta)}\right)
$$

where $A$ is the upslope contributing area and $\beta$ is the local slope angle. The higher TWI of a cell has, the higher tendency it has to accumulate water, and thus the higher likelihood of wetland presence. Traditionally, coarse-resolution DEMs (e.g., the USGS National Elevation Dataset [NED] with 10-30 m resolution) have been used to derive TWI. More recently, highresolution LiDAR-based DEMs have been used to derive TWI and facilitate forested wetland mapping (Lang et al. 2013). In addition to the TWI, other algorithms have been developed to extract surface depressions and map depressional wetlands based on LiDAR-based DEMs in conjunction with aerial photographs, such as the stochastic depression analysis method for mapping vernal pools ( $\mathrm{Wu}$ et al. 2014) and the localized contour tree method for mapping prairie wetlands (Wu and Lane 2016). An emerging open-source GIS software package called Whitebox Geospatial Analysis Tools (Whitebox GAT) also provides a number of geoprocessing tools for computing topographic metrics based on DEMs (Lindsay 2016).

\section{Wetland Classification}




\subsection{Geospatial Data}

Geospatial data for wetland mapping and monitoring include imagery collected by a variety of airborne or satellite sensors. These sensors can be broadly divided into passive and active sensors. Passive sensors measure electromagnetic radiation naturally reflected from the Earth's surface, which usually takes place during the daytime when the reflected energy from the sun is detectable by the sensor. In contrast, active sensors emit radiation using their own energy source toward the Earth's surface and measure the returned signals, which can acquire imagery both day and night under all weather conditions. Geospatial data acquired by passive sensors include aerial photography, multispectral imagery, and hyperspectral imagery. In contrast, LiDAR data and SAR imagery are collected by active sensors.

Aerial photography has been used for wetland mapping for many decades. With the technological advances, image quality collected by aerial photography has been improving, from initially black and white (panchromatic), to true color (RGB), and then to color infrared (CIR). Aerial photographs are commonly collected by states and local governments. For example, the State of Massachusetts collected 1:12,000 scale CIR aerial photographs to conduct a statewide inventory of potential vernal pool habitats (Burne 2001). One of the most common sources of aerial photography in the United States is the USDA National Agriculture Imagery Program (NAIP) initiated in 2002. The original five-year imagery acquisition cycle has been upgraded to a three-year cycle since 2009. The statewide NAIP imagery can be freely downloaded from the USDA Geospatial Data Gateway (USDA 2016). These high-resolution natural color and CIR aerial imagery have been used in numerous wetland studies (see examples in Enwright et al. 2011; Johnston 2013; Vanderhoof et al. 2016; Wu and Lane 2016).

Similar to aerial photographs, multispectral satellite imagery are collected by passive sensors. In addition to the visible (Red, Green, Blue) and near-infrared (CIR) portions of the electromagnetic spectrum, many satellite sensors also collect information on longer wavelengths, such as the short-wave infrared (SWIR) and thermal infrared (TIR). The most commonly used multispectral satellite sensors for wetland mapping include Landsat MSS/TM/ETM+/OLI, MODIS, AVHRR, SPOT-4/5/6/7, IKONOS, QuickBird, GeoEye-1, RapidEye, Sentinel-2, WorldView-1/2/3/4, among others. Comprehensive reviews of these commonly used satellite sensors for wetland mapping can be found in Ozesmi and Bauer (2002), Klemas (2011), and Lang et al. (2015). Compared to aerial photography, satellite sensors can provide multispectral imagery with finer spectral and better temporal resolutions, which are essential for classifying wetland vegetation types and analyzing wetland water dynamics.

In addition to aerial photography and multispectral imagery, LiDAR data have increasingly been incorporated into the wetland mapping process. LiDAR sensors are active systems that use laser pulses to measure ranges to the Earth, producing precise $(x, y, z)$ measurements in the form of LiDAR point clouds. High-resolution DEMs can then be derived from LiDAR point clouds by using interpolation algorithms. Importantly, the LiDAR-based DEMs can be used to compute various topographic metrics, which serve as essential wetland indicators as noted earlier. Although LiDAR sensors are primarily used to generate precise information on surface elevation, some LiDAR sensors can also record LiDAR intensity, which represents the returned signal strength relative to the emitted energy. Since most LiDAR sensors operate in the near-infrared spectrum, laser lights are strongly absorbed by water, resulting in very weak or no signal returns. As a result, water areas appear as dark features in the LiDAR intensity imagery. Therefore, LiDAR intensity data are particularly useful for 
mapping surface water and wetland inundation extent. A number of studies have reported improved accuracy of wetland inundation mapping by using LiDAR intensity data with simple thresholding techniques (Huang et al. 2011b; Lang and McCarty 2009; Wu and Lane 2016). It is worth noting the high-resolution DEMs can also be derived from aerial imagery acquired using other emerging geospatial technologies such as unmanned aerial systems (UAS) or drones. Two of the leading software packages for processing drone imagery include Drone2Map for ArcGIS (ESRI 2016) and ENVI OneButtion (Harris Geospatial Solutions 2016), both of which can take raw imagery from drones and create high-resolution orthomosaics and digital surface models for wetland mapping.

\subsection{Classification Methods}

Wetland classification methods have been developing for decades along with methods for land use and land cover classification. Common classification methods can be divided into two broad categories: supervised classification and unsupervised classification. In a supervised classification, the analyst first selects training samples (i.e., homogeneous and representative image areas) for each land cover class and then use them to guide the computer to identify spectrally similar areas for each class. The selection of training samples can be based on field data collection or expert knowledge. The most common supervised classification methods include maximum likelihood, parallelepiped, minimum distance, decision tree, random forest, support vector machine, among others (Lang et al. 2015). Unsupervised classification, however, does not start with training samples. Instead, the analyst specifies the desired number of classes, and then the computer automatically groups pixels that are statistically similar into categories using clustering algorithms. The most commonly used cluster algorithms include K-Means, Iterative Self-Organizing Data Analysis Technique (ISODATA), and agglomerative hierarchical (Duda and Canty 2002). The iterative clustering process results in a preset number of 'spectral classes', which can then be assigned class labels and become 'information classes'. Unsupervised classification is particularly useful when field data or prior knowledge about the study area are not available. Some studies used a hybrid approach that combines unsupervised and supervised classification methods with field survey (Lane et al. 2014).

Supervised and unsupervised methods have been used for decades for classifying remote sensing images. They are pixel-based classification methods solely based on spectral information (i.e., Digital Number [DN] values), which often result in 'salt and pepper' effect in the classification result. To overcome the issues associated with pixel-based classification methods, object-based image analysis (OBIA) methods for image classification have been developed (Blaschke 2010; Liu et al. 2010). The OBIA approach can incorporate spectral, spatial, textural, and contextual information into the classification process. Numerous studies have reported that OBIA approach can achieve greater accuracy for wetland mapping than traditional pixel-based approach (Joseph et al. 2015). Trimble eCognition Developer is one the of most popular software packages for object-based image classification and analysis (Trimble 2016).

\subsection{Classification Systems}


There are two kinds of wetland classification systems: horizontal and vertical (Tiner 2009a). A horizontal classification system classifies wetlands into a finite number of types based on the major characteristics of each type. The wetland types in the horizontal classification system are mutually exclusive and highly generalized. For example, some commonly used terms such as marsh, swamp, bog, and fen belong to the horizontal classification system. In terms of water permanence (i.e., frequency and duration of water ponding), wetlands can be classified into permanently flooded, semi-permanently flooded, seasonally flooded, temporarily flooded and ephemeral wetlands (Sloan 1972). Similarly, based on their topographic position, wetlands can be classified into marine, estuarine, lotic (rivers and streams), lentic (lakes), terrene, and geographically isolated wetlands (Tiner 2015a).

Vertical classification systems utilize a hierarchical approach that classifies wetlands into a few general types and then further subdivides each type into more and more detailed types. Higher-level wetland types share more generalized characteristics, such as topographic position and water source, while lower-level wetland types are based on more specific characteristics (e.g., dominant vegetation species, water chemistry, substrate characteristics, and water level fluctuations) (Tiner 2015a). A good example of vertical classification systems is the Cowardin et al. (1979) classification hierarchy developed and adopted by the U.S. Fish and Wildlife Services (FWS) for conducting a nationwide wetland inventory. This hierarchical classification system classifies wetlands and deepwater habitats into five levels, including system, subsystem, class, subclass, and modifiers. More information about this Cowardin et al. (1979) classification system will be described in Section 4.2. It should be noted that vertical classifications usually require high-resolution aerial photographs or submeter satellite imagery in conjunction with field verification. Traditional medium-resolution satellite data are generally not suitable for developing vertical classification systems.

\section{Current Large-scale Wetland Inventories}

Significant progress has been made in mapping large-scale (e.g., global-scale, regionalscale) wetlands during the past decades. A number of large-scale wetland inventories have been developed by various individuals, agencies, and organizations (Channan et al. 2014; Cowardin et al. 1979; Dugan 1993; Feng et al. 2016; Finlayson et al. 1999; Fluet-Chouinard et al. 2015; Gumbricht 2012; Lehner and Döll 2004; Ramsar Convention Secretariat 2016; Rebelo et al. 2009; Zheng et al. 2015). As noted earlier, there is no universally accepted definition of wetlands due to the diversity of wetlands. As a result, the currently available large-scale wetland inventories are not consistent in their wetland definition, methodology, or wetland classification system. The inconsistencies between these existing large-scale wetland inventories make it difficult to conduct comparative analysis. Nevertheless, these wetland inventories do represent the best available wetland datasets and could serve as a good starting point for analyzing wetland extents at a global or regional scale.

\subsection{Global-scale Wetland Inventories}

The advancement of remote sensing technology has enabled satellite to provide global land cover images with increasing spatial, temporal, and spectral resolutions. Currently available wetland inventories at the global scale are inconsistent in many ways, such as wetland definition, wetland classification system, wetland classification method, data type, and spatial resolution. A list of the existing global datasets of wetlands is shown in Table 1. 
Table 1. Overview of existing global datasets of wetlands

\begin{tabular}{|c|c|c|c|c|c|}
\hline No. & Name & Data source & Data types and resolution & Description & Website \\
\hline 1 & $\begin{array}{l}\text { Ramsar Wetlands } \\
\text { Database }\end{array}$ & $\begin{array}{l}\text { Ramsar Convention } \\
\text { (2016) }\end{array}$ & $\begin{array}{l}\text { Global representative } \\
\text { point coordinates }\end{array}$ & $\begin{array}{l}\text { Currently comprises } 2243 \text { wetland sites worldwide, } \\
\text { covering approximately } 2.16 \text { million } \mathrm{km}^{2}\end{array}$ & https://rsis.ramsar.org/ \\
\hline 2 & $\begin{array}{l}\text { Global Lakes and } \\
\text { Wetlands Database } \\
\text { (GLWD) }\end{array}$ & Lehner and Döll (2004) & $\begin{array}{l}\text { Global raster map; } \\
\text { 30-second resolution }\end{array}$ & $\begin{array}{l}\text { Comprises lakes, reservoirs, rivers and different wetland } \\
\text { types; wetlands were estimated to reach about } 8-10 \\
\text { million } \mathrm{km}^{2} \text {, or } 6.2-7.6 \% \text { of the global land surface area }\end{array}$ & http://www.worldwildlife.org/ \\
\hline 3 & $\begin{array}{l}\text { Global Ecological Land } \\
\text { Units (ELUs) }\end{array}$ & USGS and ESRI (2015) & $\begin{array}{l}\text { Global raster map; } \\
\text { 250-m resolution }\end{array}$ & $\begin{array}{l}\text { Comprises areas of distinct bioclimate, landform, } \\
\text { lithology, and land cover that form the } \\
\text { basic components of terrestrial ecosystem structure; } 3,639 \\
\text { different combinations or ELUs }\end{array}$ & http://esriurl.com/eco/ \\
\hline 4 & $\begin{array}{l}\text { ESA CCI Global Land } \\
\text { Cover Dataset }\end{array}$ & ESA (2016) & $\begin{array}{l}\text { Global rater map; } \\
300-\mathrm{m} \text { resolution }\end{array}$ & $\begin{array}{l}\text { Includes three land cover maps corresponding to the } \\
\text { different epochs 2000, 2005, and } 2010 \text { that classifies land } \\
\text { cover into one of } 36 \text { classes }\end{array}$ & http://www.esa-landcover-cci.org/ \\
\hline 5 & $\begin{array}{l}\text { Global Mosaics of the } \\
\text { standard MODIS land } \\
\text { cover }\end{array}$ & Channan et al. (2014) & $\begin{array}{l}\text { Global raster map; } \\
\text { 5-minute resolution }\end{array}$ & $\begin{array}{l}\text { Based on MODIS land cover type data product } \\
\text { (MCD12Q1), classified as } 17 \text { land cover types, including } \\
\text { 'permanent wetlands' }\end{array}$ & http://www.landcover.org/ \\
\hline 6 & Global Water Frequency & Feng et al. (2015) & $\begin{array}{l}\text { Global raster map; } \\
\text { 30-m resolution }\end{array}$ & $\begin{array}{l}\text { Contains estimates of the percentage of water occurrence } \\
\text { among all valid Landsat observations circa 2000; it } \\
\text { provides a more comprehensive estimation of global } \\
\text { water area and changes in compare to static inland water } \\
\text { maps. }\end{array}$ & http://www.landcover.org/ \\
\hline 7 & $\begin{array}{l}\text { CIFOR World Wetland } \\
\text { Distribution }\end{array}$ & Gumbricht (2012) & $\begin{array}{l}\text { Global raster map; } \\
236-\mathrm{m} \text { resolution }\end{array}$ & $\begin{array}{l}\text { Covers the tropics and sub tropics; consists of seven } \\
\text { classes: Fen, Bog-ombrotrophic peat domes, Riverine, } \\
\text { Mangrove, Flood-out, Floodplain, Swamp and Marsh }\end{array}$ & http://www.cifor.org/ \\
\hline 8 & $\begin{array}{l}\text { Global Inundation Extent } \\
\text { from Multi-Satellites } \\
\text { (GIEMS) }\end{array}$ & $\begin{array}{l}\text { Fluet-Chouinard et al. } \\
\text { (2015) }\end{array}$ & $\begin{array}{l}\text { Global raster map; } \\
\text { 500-m resolution }\end{array}$ & $\begin{array}{l}\text { Provides the surface water extent and dynamics over the } \\
\text { globe and over a long time record (1993-2007), based on a } \\
\text { collection of satellite observations. }\end{array}$ & https://lerma.obspm.fr/ \\
\hline 9 & World Water Bodies & ESRI (2016) & $\begin{array}{l}\text { Global vector map; } \\
1: 2 \text { million resolution }\end{array}$ & $\begin{array}{l}\text { Includes } 2.23 \text { million polygons, classified as 'Inland } \\
\text { intermittent', 'Inland perennial', and 'Dry salt flat' }\end{array}$ & http://www.arcgis.com/ \\
\hline 10 & $\begin{array}{l}\text { Global Distribution of } \\
\text { Wetlands Map }\end{array}$ & USDA-NRCS (1997) & $\begin{array}{l}\text { Global raster map; } \\
\text { 1:5 million resolution }\end{array}$ & $\begin{array}{l}\text { Based on a reclassification of the FAO-UNESCO Soil Map } \\
\text { of the World combined with a soil climate map; five major } \\
\text { wetland classes were identified }\end{array}$ & http://www.nrcs.usda.gov/ \\
\hline 11 & Global Wetland Project & ESA and Ramsar (2012) & Global vector map & $\begin{array}{l}\text { Involves } 10 \text { countries in the Northern Africa and Middle } \\
\text { East }\end{array}$ & http://www.globwetland.org/ \\
\hline 12 & $\begin{array}{l}\text { Wetlands Map of the } \\
\text { UNEP-WCMC }\end{array}$ & $\begin{array}{l}\text { UNEP-WCMC (1993); } \\
\text { Dugan (1993) }\end{array}$ & Global vector map & $\begin{array}{l}\text { Includes } 24,685 \text { wetland and lake polygons; classified in } \\
\text { eight types }\end{array}$ & https://www.unep-wcmc.org/ \\
\hline
\end{tabular}

(1)

(1)

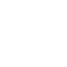

.

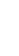

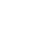


Some current wetland maps at the global scale were extracted from different global land cover products derived from remotely sensed data with a spatial resolution ranging from 5minute to $30-\mathrm{m}$. Despite the inconsistencies and limitations of these existing inventories, they provide important information about the global extent of wetlands and serve as valuable data sources for wetland research, conservation, and management.

The Ramsar Convention, also known as the Convention on Wetlands of International Importance, is an international treaty for promoting conservation and sustainable use of wetland habitats, especially as habitats for migratory waterfowl. It was named after the city of Ramsar in Iran, where the Convention was first held in 1971. Initially, there were only seven countries signed the agreement on December 21, 1975. Ever since then, the number of contracting countries has been growing. Currently, the Convention has 169 contracting countries. As of November 2016, there are 2243 sites worldwide that the Ramsar Convention designated as wetlands of international importance, covering approximately 2.16 million $\mathrm{km}^{2}$. The spatial distribution of these Ramsar sites is shown in Figure 1. The country with the highest number of Ramsar sites is the United Kingdom with 170 sites, while the country with the highest total area of Ramsar wetlands is Bolivia with $148,424 \mathrm{~km}^{2}$. The GIS data for the Ramsar sites are available through the Ramsar Sites Information Service (Ramsar Convention 2016), which provides point coordinates as well as polygons (partially) for Ramsar sites in the ESRI shapefile format.

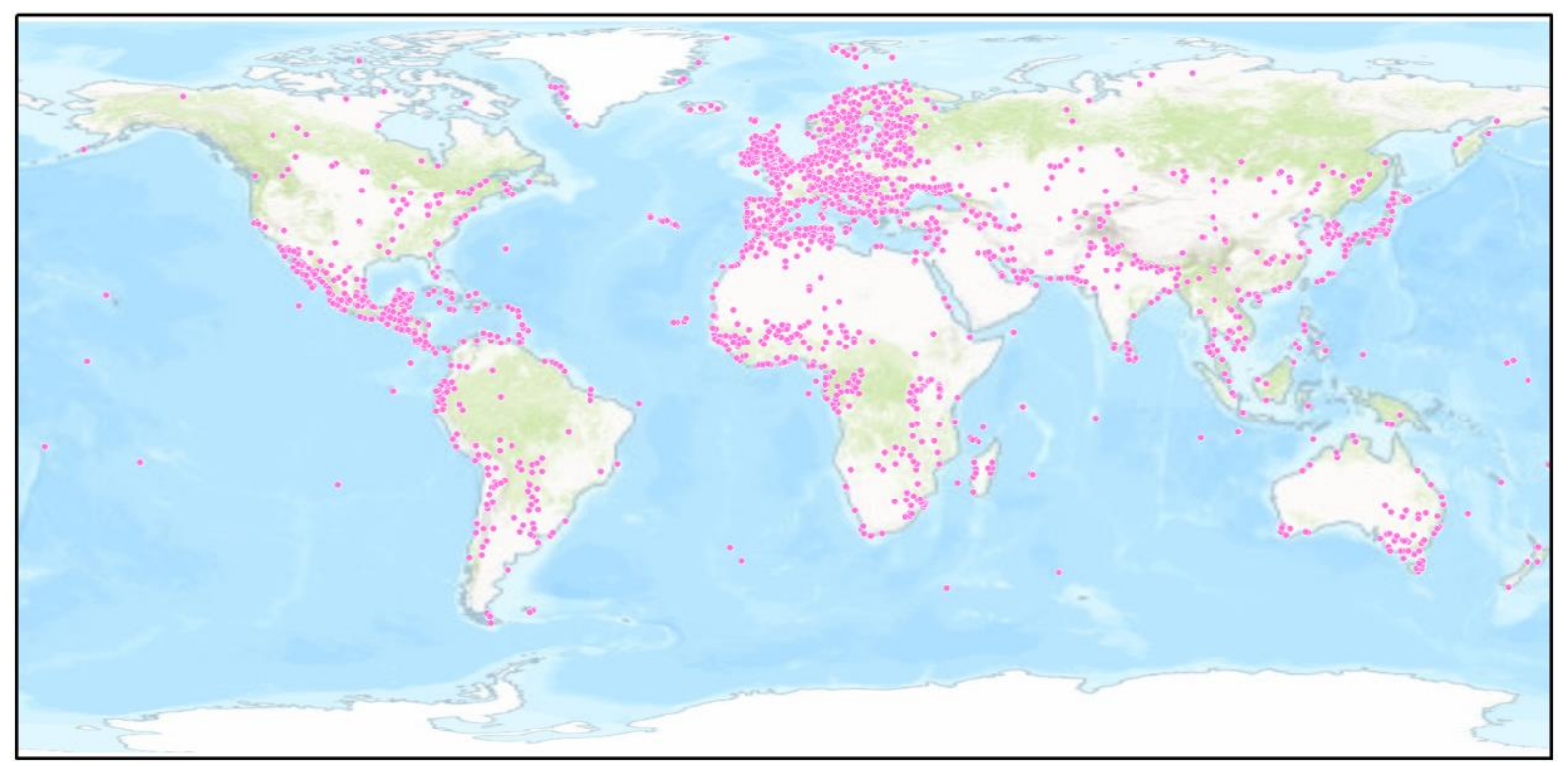

Figure 1. Global distribution of Ramsar sites. (Source: Ramsar Convention)

Lehner and Döll (2004) developed a Global Lakes and Wetlands Database (GLWD) in the form a global raster map at 30-second resolution. They estimated that global wetlands cover approximately $8.3-10.2$ million $\mathrm{km}^{2}$ or $6.2-7.6 \%$ of the global land surface area (excluding Antarctica and Greenland). Geographically, nearly half of the global wetlands occur in the high northern latitudes between $50^{\circ}$ and $70^{\circ} \mathrm{N}$ in boreal and arctic regions where permafrost, bogs, and fens are abundant (Figure 2). The remainder of global wetlands are primarily located in the humid tropical and subtropical regions where forested wetlands and marshes are dominant (Melton et al. 2013; Tiner 2009b). It should be noted that the estimated global wetland extents reported in the literature vary significantly, which have an almost three-fold difference between the lower and upper estimates (4.3-12.9 million $\left.\mathrm{km}^{2}\right)$. 


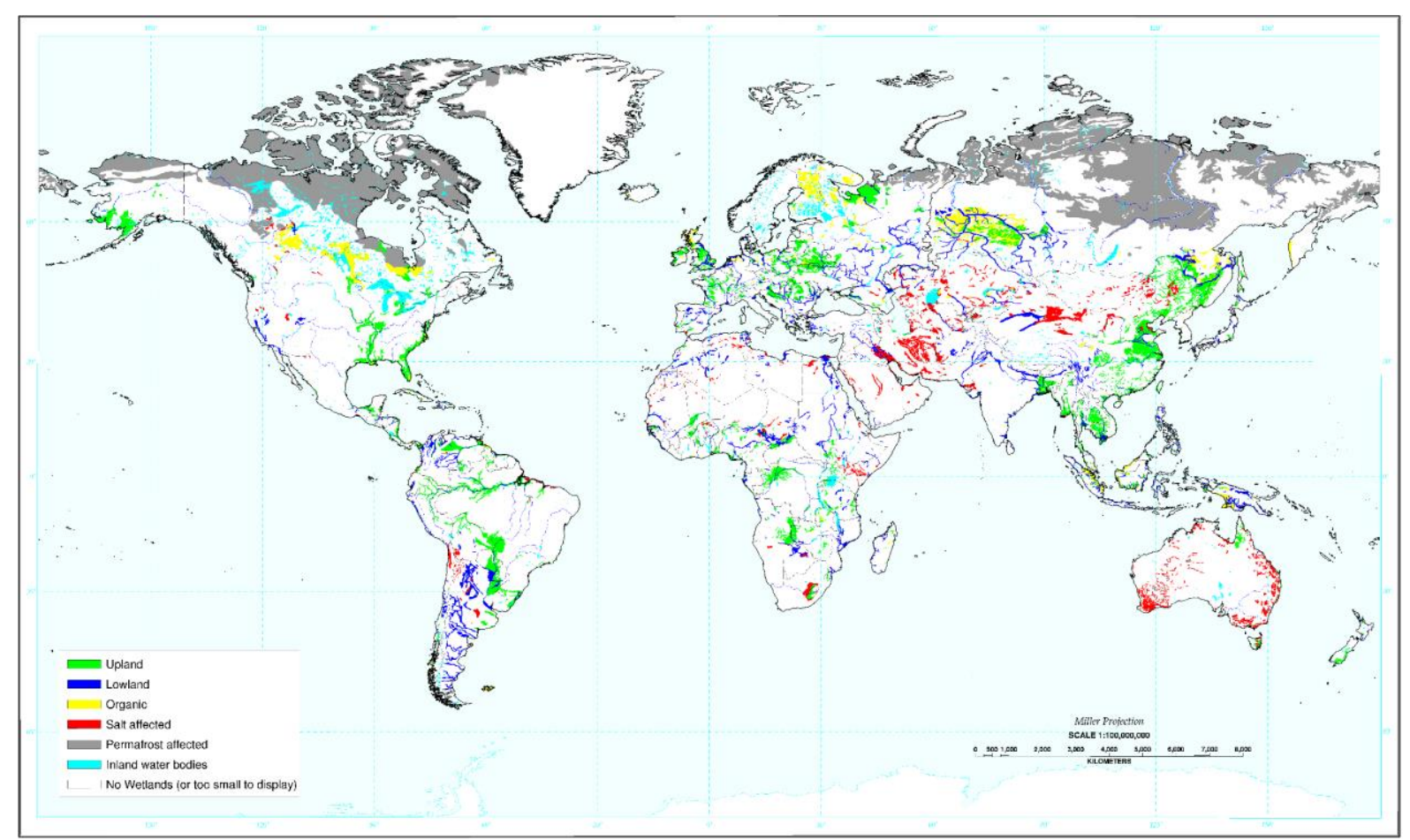

Figure 2. Global Lakes and Wetlands Database (GLWD). (Source: USDA-NRCS)

In addition to the above mentioned global wetland inventories developed specifically for mapping global wetland resources, there are a number of global land cover or water datasets from which wetlands can be extracted (see Table 1). For example, the European Space Agency's (ESA) Climate Change Initiative (CCI) produced a Global Land Cover Map for the 2010 epoch, which is a 300-m resolution raster that classifies global land cover into one of 36 classes (Figure 3). Data for this Global Land Cover Map 2010 epoch were collected from 2008 to 2012 by the ESA's MERIS satellite. It should be noted that the ESA's Global Land Cover Map does not have a dedicated wetland land cover type. Nevertheless, there are some wetland-related land cover types, such as water bodies, shrub or herbaceous flooded, tree flooded - fresh water, tree flooded - saline water. These wetland-related land cover types can be combined to extract global wetland extent. More recently, the Association of American Geographers (AAG) published a groundbreaking 250-m resolution global map and database of Ecological Land Units (ELUs), which was derived from a stratification of the earth into unique physical environments and their associated vegetation (Figure 4). The mapping approach first characterizes the climate regime, landforms, lithology, and land cover of the Earth, and then models terrestrial ecosystems as a combination of those four land surface components (Sayre et al. 2014). These four components resulted in 3,639 different combinations or ELUs. This global map of ELUs, implemented by USGS and ESRI, represents the latest collective efforts to map standardized, high-resolution terrestrial ecosystems of the Earth. 


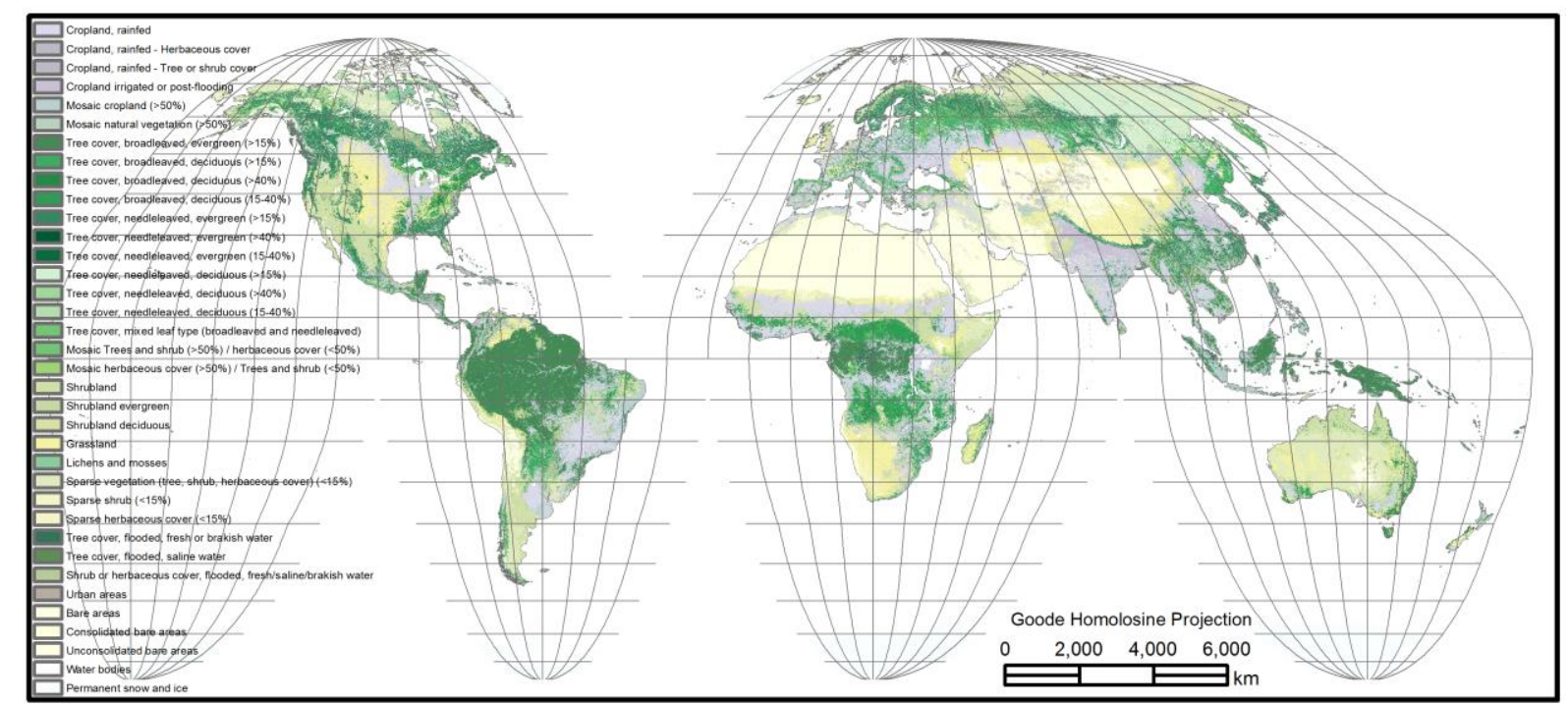

Figure 3. 300-m resolution Global Land Cover Map (2010 epoch). (Source: ESA-CCI)

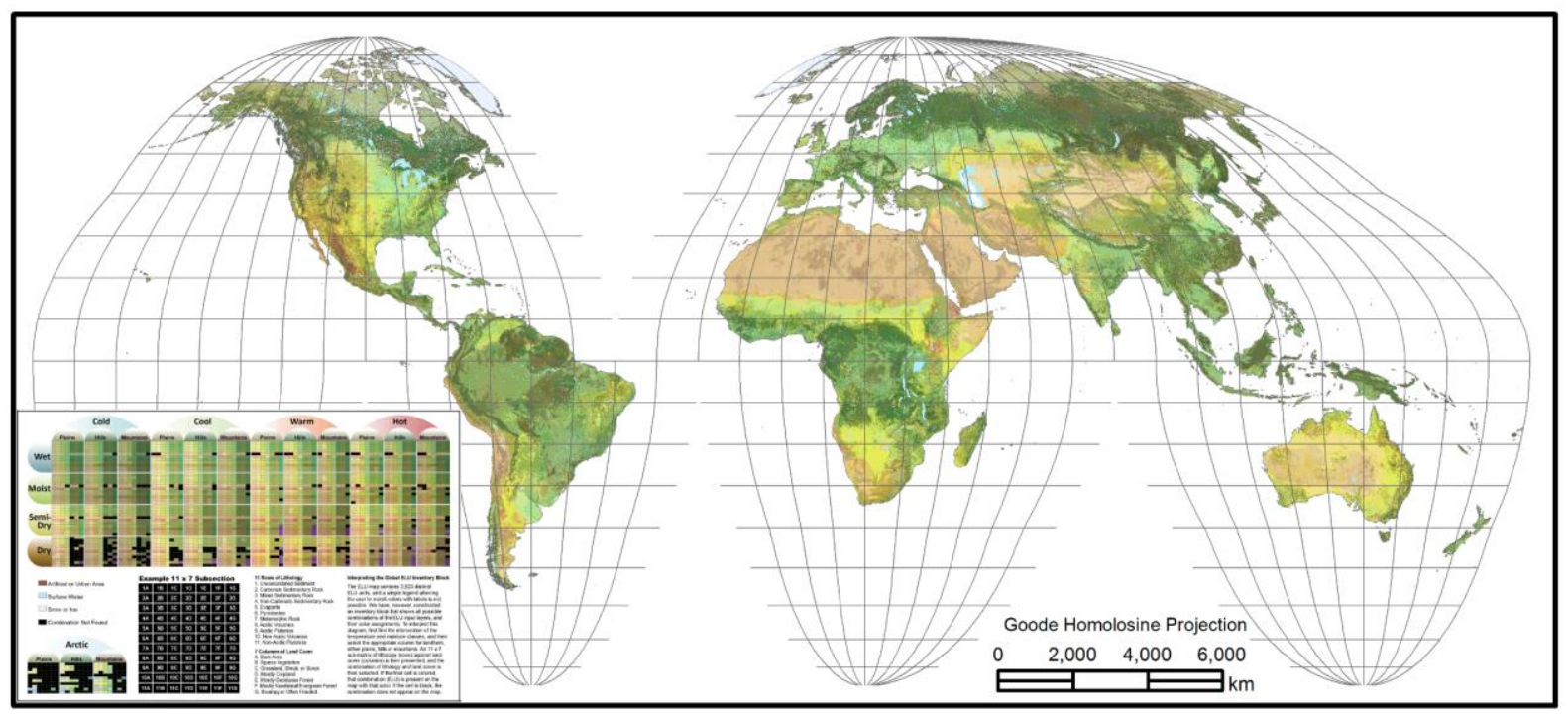

Figure 4. 250-m resolution global map and database of Ecological Land Units (ELUs). (Source: USGS and ESRI)

\subsection{U.S. National Wetlands Inventory}

In 1974, the U.S. Fish and Wildlife Services (FWS) initiated the National Wetlands Inventory (NWI) Program to conduct a nationwide inventory of wetlands in the U.S., aiming to provide decision-makers with information on the distribution and status of wetlands to aid in wetland conservation efforts (Tiner 2009c). To achieve this goal, the NWI developed a national wetland classification system (Cowardin et al. 1979), which has now become the federal standard for wetland classification and has been adopted for use in other countries. Compared to the currently available global wetland inventories, the NWI classification system has more detailed wetland types for both wetlands and deepwater habitats. The classification is primarily based on vegetation, hydrologic regime, soil, salinity, and the location of wetlands. It is a hierarchical classification system consisted of five basic levels (from general to detailed): system, subsystem, class, subclass, and modifiers. The five major systems are: Marine (open ocean and its associated coastline), Estuarine (estuary and associated tidal and adjacent tidal wetlands), Riverine (wetlands and deepwater habitats within banks of rivers 
and streams), Lacustrine (permanently flooded lakes and reservoirs, intermittent lakes, and tidal lakes), and Palustrine (inland vegetated wetlands, such as marshes, swamps, bogs, fens, ponds and prairie wetlands) (Tiner 2009a). Each system (except Palustrine) is further subdivided into subsystems. More information about the classification system can be found in Cowardin et al. (1979).

The NWI maps were primarily produced by manually interpreting the mid-1980s aerial photographs at a scale of $1: 24 \mathrm{~K}$ with subsequent support from soil surveys and field verifications. So far, the NWI has produced maps for more than $90 \%$ of the conterminous United States, the entire state of Hawaii, and 30\% of Alaska (Tiner 2009c). The spatial data of the entire NWI has been made available through the internet via the Wetlands Mapper online tool (USFWS 2016) and can be downloaded in the format of ESRI Geodatabase or Shapefile. The NWI target mapping unit (i.e., the minimum sized wetland that is consistently mapped) for different regions of the U.S. varies between 1000-20,000 $\mathrm{m}^{2}$ (or 0.1-2.0 ha), depending on the types of aerial imagery used and the types of wetland being mapped (Tiner 1997). It is generally accepted that NWI mapping is most accurate for permanently flooded wetlands where distinct changes between vegetation, hydrology, and soil occur at the wetland boundary (Lang et al. 2015). In contrast, other wetland types, such as seasonally and temporarily flooded wetlands, ephemeral wetlands, and forested wetlands, are mapped more conservatively. It should be noted that NWI is a static dataset that might not reflect current wetland conditions, especially in areas where changes have occurred over the past 30 years due to natural changes and human activities. Nevertheless, NWI remains the most comprehensive nationwide wetland inventory in the U.S. and does provide a valuable data source for wetland location information. Great efforts have been made by the U.S. FWS and some states to update NWI by incorporating additional data and advanced remote sensing techniques.

\section{Case Study: Mapping Prairie Wetlands and Surface Hydrologic Flow Pathways Using LiDAR Data and Aerial Imagery}

\subsection{Introduction}

The Prairie Pothole Region (PPR) of North America encompasses a vast area of approximately 715,000 km², including parts of five north-central U.S. states (Montana, North Dakota, South Dakota, Minnesota, and Iowa) and three south-central Canadian provinces (Alberta, Saskatchewan, and Manitoba) (Figure 5(a)). The landscape of the PPR is characterized by millions of closed-basin wetland depressions (see Figure 5(b)) in clay-rich glacial deposits left by the last glacial retreat (van der Kamp et al. 2016; Winter 1989). The PPR is considered as one of the largest and most productive wetland areas in the world (Keddy 2010; Steen et al. 2014). These wetland depressions, commonly known as potholes, possess important hydrological and ecological functions, such as providing critical habitat for many migratory and breeding waterbirds (Minke 2009; Rover and Mushet 2015), acting as nutrient sinks (Oslund et al. 2010), and storing surface water that can attenuate peak runoff during a flood event (Huang et al. 2011b). The potholes range from a relatively small area of less than $100 \mathrm{~m}^{2}$ to as large as 30,000 $\mathrm{m}^{2}$, with an estimated median size of $1600 \mathrm{~m}^{2}$ (Huang et al. 2011a; $\mathrm{Wu}$ and Lane 2016; Zhang et al. 2009). The depths of potholes are generally less than $1 \mathrm{~m}$ with varying water permanency (ephemeral, temporal, seasonal, semi-permanent, and permanent) (Sloan 1972). Due to their small size and shallow depth, these wetlands are highly sensitive to 
climate variability and are vulnerable to ecological, hydrological, and anthropogenic changes. Their ponded water areas are highly variable resulting from alternating wet and dry periods. In extremely wet periods, many small wetland depressions may coalesce to form larger wetland depressions through the fill-spill mechanism. The time-series aerial imagery in Figure 6 clearly demonstrates the ponded water dynamics of prairie wetland depressions.

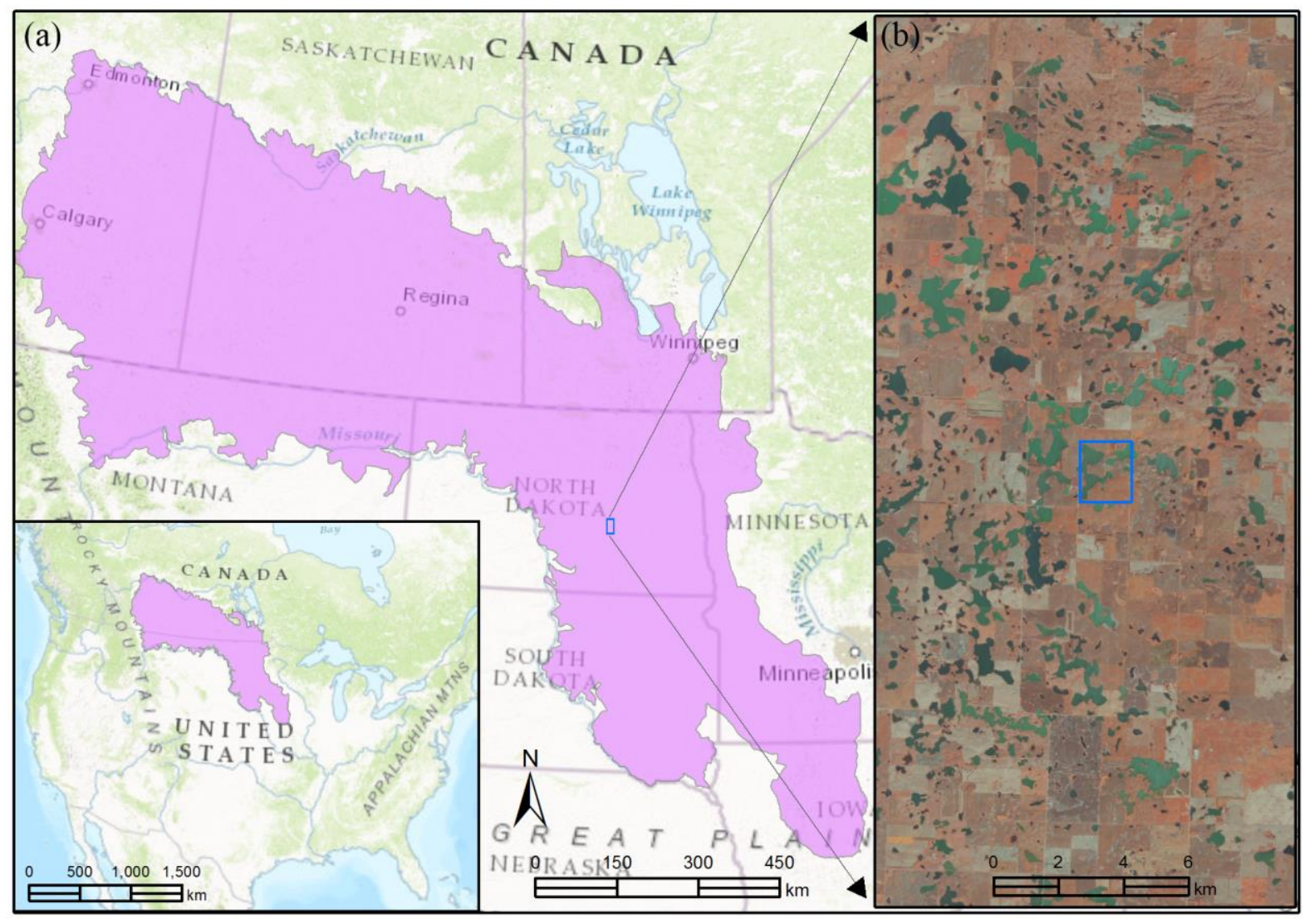

Figure 5. The Prairie Pothole Region (PPR) of North America. (a) Geographic extent of the PPR; and (b) The aerial photograph shows an enormous amount of prairie pothole wetlands formed by the last glacial retreat. 


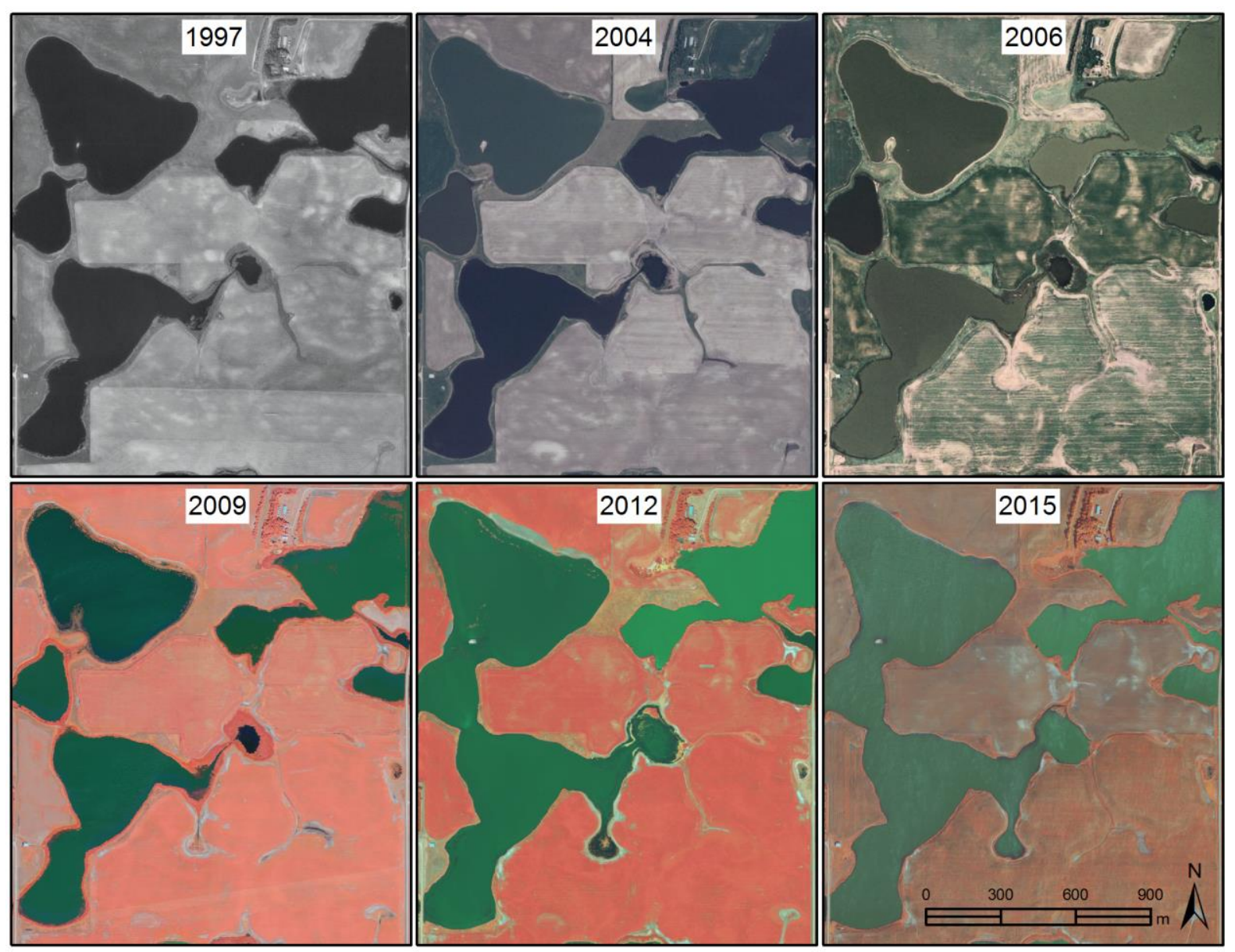

Figure 6. Time-series aerial photographs illustrate the dynamic nature of prairie pothole wetlands under alternating wet and dry periods.

Prairie wetlands in the PPR have been extensively drained and filled for agricultural purposes, which is considered as the greatest source of wetland loss in the PPR (Johnston 2013). In a report to the United States Congress on the status of wetland resources, Dahl (1990) estimated that the lower 48 states lost an estimated $53 \%$ of their original wetlands over a period of 200 years between the 1780's and the 1980's. More recently, Dahl (2014) reported that the total wetland area in the PPR declined by an estimated $301 \mathrm{~km}^{2}$ or $1.1 \%$ between 1997 and 2009. This represents an average annual net loss of $25 \mathrm{~km}^{2}$. Regarding the number of depressions, it was estimated that the wetland depressions declined by over 107,177 or $4 \%$ between 1997 and 2009 (Dahl 2014). The extensive wetland drainage and removal have increased precipitation runoff into regional river basins, which is largely responsible for the increasing magnitude and frequency of flooding events in the PPR (Bengtson et al. 1999; Miller and Nudds 1996; Todhunter and Rundquist 2004). Concerns over flooding along rivers in the PPR have stimulated interest in developing hydrologic models to simulate the effects of depression storage on peak river flows (Gleason et al. 2008; Gleason et al. 2007; Huang et al. 2011b; Hubbard and Linder 1986). Since most of these prairie wetlands do not have surface outlets or well-defined surface water connections, they are generally considered as geographically isolated wetlands (GIWs) (Cohen et al. 2016; Lane and D'Amico 2016). Despite their lack of an apparent surface water connection, it is important to note that these wetlands may be hydrologically connected to other wetlands and waterbodies through groundwater or intermittent surface water connections during extremely wet periods (Leibowitz et al. 2016; Tiner 2015a). 
A number of recent studies focusing on the hydrologic connectivity of prairie wetlands have been reported in the literature. For example, Chu (2015) proposed a puddle-to-puddle modeling framework to delineate prairie wetlands and characterize their dynamic hydrotopographic properties in the Cottonwood Lake area $\left(2.55 \mathrm{~km}^{2}\right)$ using a $10-\mathrm{m}$ resolution DEM. Vanderhoof et al. (2016) examined the effects of wetland expansion and contraction on surface water connectivity in the PPR using time-series Landsat imagery. Ameli and Creed (2016) developed a physically-based subsurface-surface hydrological model to characterize both the subsurface and surface hydrologic connectivity of prairie wetlands and explore the time and length variations in these connections to a river. In a comprehensive overview of the hydrology of prairie wetlands, Hayashi et al. (2016) highlighted that prairie wetlands and catchments should be considered as highly integrated hydrological units because the existence of prairie wetlands depends on lateral inputs of runoff water from their catchments in addition to direct precipitation. However, few studies on the hydrology of prairie wetlands have treated wetlands and catchments as integrated hydrological units. Furthermore, highresolution LiDAR data have rarely been used in broad-scale (e.g., basin- or subbasin-scale) studies to delineate wetland catchments and model wetland connectivity in the PPR.

In this case study, a semi-automated framework was proposed to delineate nested hierarchical wetland depressions, their corresponding wetland catchments, and surface water connectivity using high-resolution LiDAR data (Wu and Lane 2017). The nested hierarchical structure of wetland depressions and catchments was identified and quantified using the localized contour tree method (Wu et al. 2015). The surface water connectivity between wetlands and streams was characterized using the least-cost path algorithm. The derived surface water flow network successfully captured those intermittent flow paths that were generally not available in the National Hydrography Dataset (NHD) of the PPR. The results demonstrated that the proposed framework is promising for improving overland flow modeling and hydrologic connectivity analysis.

\subsection{Methods}

In general, there are two types of surface water connectivity between prairie wetlands: fill-spill and fill-merge-spill. Whether fill-spill or fill-merge-spill occurs depends on the relative elevation of spill points and the water levels. If two adjacent wetland depressions share the same spill point (elevation), the fill-merge-spill hydrological process will occur. However, if a wetland depression has no adjacent wetland depressions sharing the same spill point, it will directly spill to a downstream waterbody or wetland. In that case, it is a fill-spill only hydrological process. Figure 7 illustrates the fill and spill dynamics of prairie wetlands. As water level gradually increases in the individual wetland depressions B and C, they will eventually begin to coalesce and form a larger wetland complex. Once the larger wetland complex is fully filled, it will spill to the downstream wetland depression D. Similarly, depressions $\mathrm{D}$ and $\mathrm{E}$ will experience the same fill-merge-spill hydrological process. On the contrary, depression A will experience the fill-spill process as no adjacent depressions sharing the same spill points are available. 


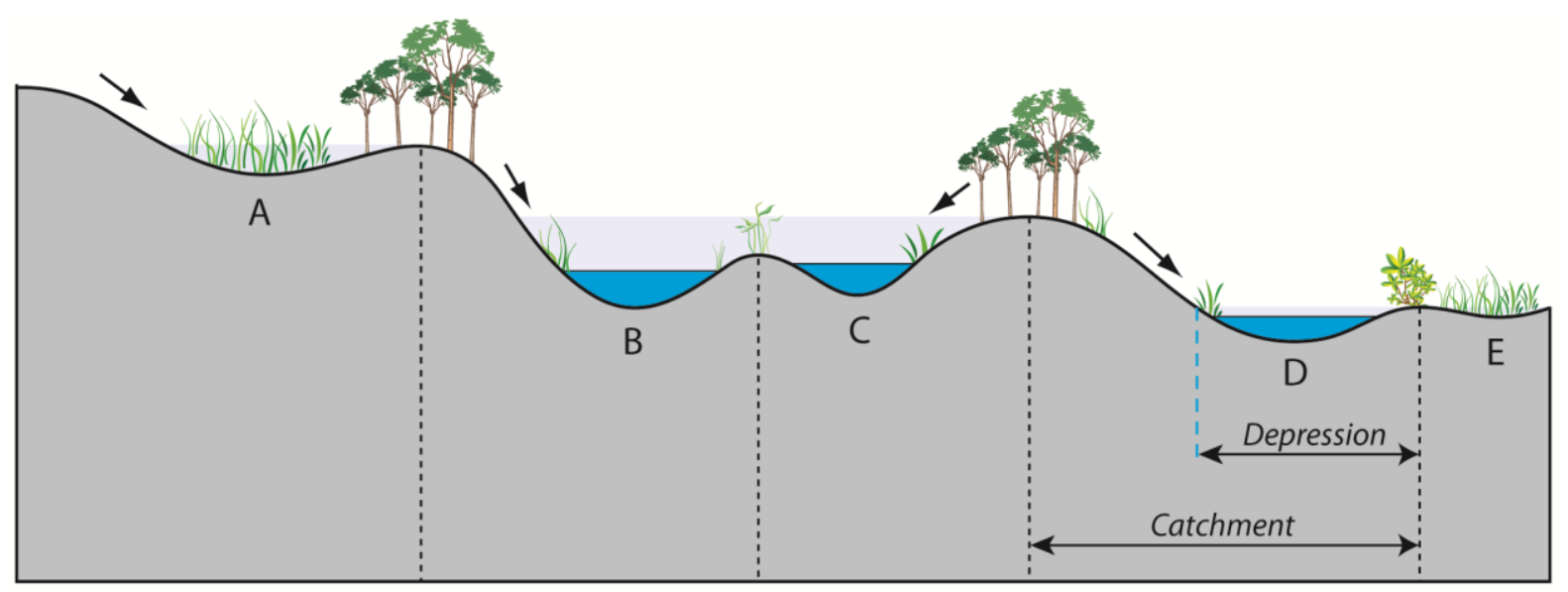

Figure 7. A schematic diagram illustrates the fill and spill dynamics of prairie wetlands.

As shown in Figure 7, both wetland depressions and catchments exhibit a nested hierarchical structure. It should be noted that the wetland depression is different from the wetland inundation area. The standing water surface of a wetland is referred to as the inundation area (see the dark-blue area in Figure 7), whereas the maximum potential ponded extent is referred to as the wetland depression (see the light-blue area in Figure 7). The wetland catchment is defined as the upslope contributing area that drains water into the wetland depression. The catchment is also known as the watershed, contributing area, or drainage basin. For example, the corresponding wetland catchment of depression B is bounded by the two vertical dashed lines surrounding it. When depressions B and C coalesce to form a larger wetland complex, the wetland catchment of the resulting wetland complex is the aggregated area of wetland catchments B and C.

In this case study, 1-m resolution LiDAR-derived DEM in conjunction with LiDAR intensity imagery were used to map prairie wetlands and surface hydrologic flow pathways. The LiDAR intensity imagery was used to delineate wetland inundation areas, whereas the LiDAR DEM was used to delineate wetland depressions, catchments, and surface hydrologic flow pathways. Thresholding techniques have been commonly applied to LiDAR intensity imagery to extract inundation areas (Lang and McCarty 2009; McCauley and Anteau 2014). The proposed methodology for delineating nested wetland catchments and flow paths is a semi-automated approach consisting of several key steps: (a) extraction of hierarchical wetland depressions using the localized contour tree method (Wu et al. 2015); (b) delineation of nested wetland catchments; (c) calculation of potential water storage; and (d) derivation of flow paths using the least-cost path search algorithm. The LiDAR-derived bare-earth DEM is used to delineate hierarchical wetland depressions and nested wetland catchments. The LiDAR intensity imagery is used to extract standing waterbodies on the ground. The potential water storage of each individual wetland depression is calculated as the volume between the standing water surface and the maximum water boundary where water overspills into downstream wetlands or waters. The flow paths representing surface water connectivity can then be derived according to the potential water storage and simulated rainfall intensity. The flowchart in Figure 8 shows the detailed procedures of the proposed framework for delineating wetland catchments and flow paths. 


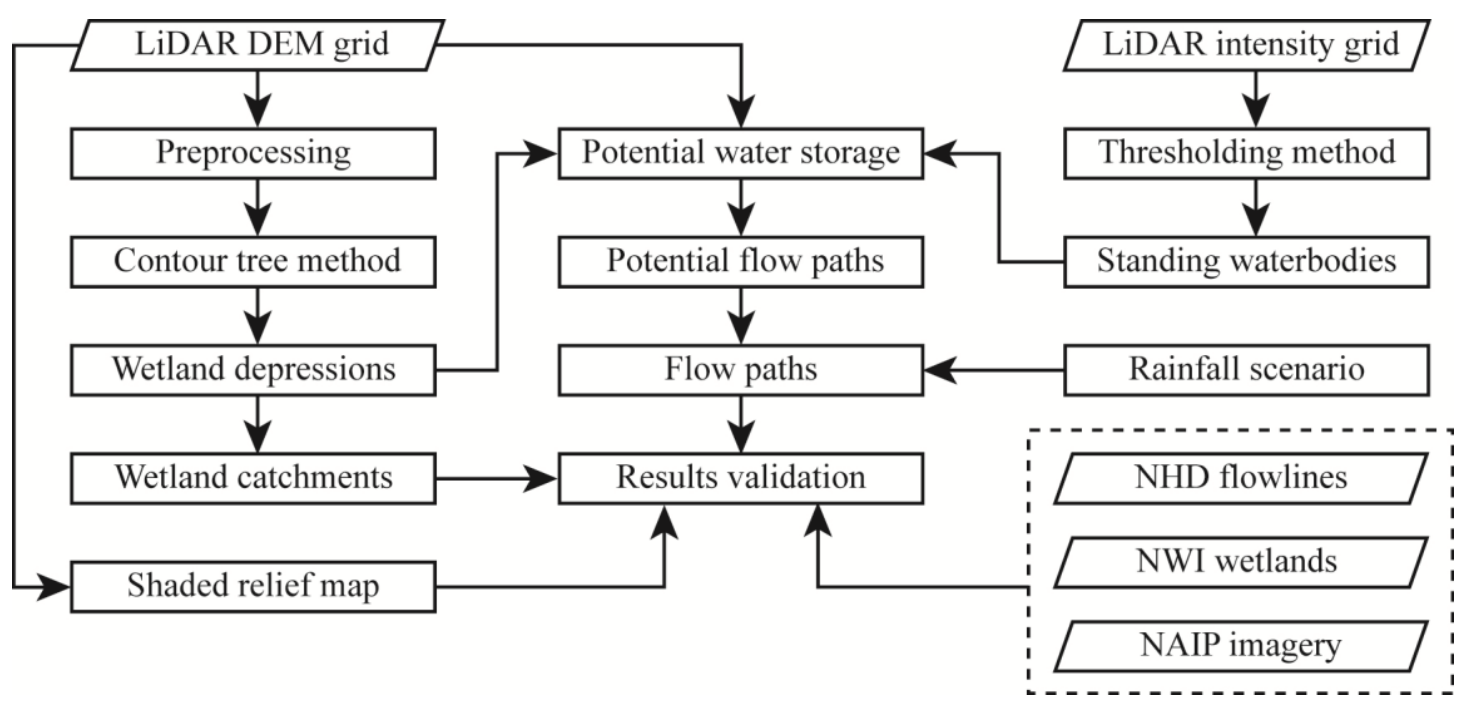

Figure 8. Flowchart of the proposed framework for delineating wetland catchments and flow paths.

To streamline the procedures for automated delineation of wetland catchments and flow paths, the proposed framework has been implemented as an ArcGIS toolbox - Wetland Hydrology Analyst. The core algorithms of the toolbox were implemented using the Python programming language. The toolbox consists of three tools: Wetland Depression Tool, Wetland Catchment Tool, and Flow Path Tool. The Wetland Depression Tool asks the user to select a DEM grid, and then executes the localized contour tree algorithm with user-specified parameters (e.g., base contour, contour interval, minimum depression size, minimum ponding depth) automatically to delineate hierarchical wetland depressions. The depressional wetland polygons can be saved as ESRI Shapefiles or a Feature Dataset in a Geodatabase. Various morphometric properties (e.g., width, length, area, perimeter, maximum depth, mean depth, volume, elongatedness, and compactness) are computed and included in the attribute table of the wetland polygon layers. The Wetland Catchment Tool uses the DEM grid and the wetland polygon layers resulted from the Wetland Depression Tool as input, and exports wetland catchment layers in both vector and raster format. The Flow Path Tool can be used to derive overland flow paths of surface water based on the DEM grid and the wetland polygon layers.

\subsection{Results and Discussion}

The proposed methods were tested in the Prairie Pothole Region of North Dakota (see Figure 9). A small portion of the results is shown in Figure 9. By comparing the inundation polygons derived from the 2011 LiDAR intensity data and the NWI polygons created in the early 1980s by the U.S. Fish and Wildlife Service, it can clearly be seen that the NWI wetlands inventory in this region is considerably out of date. It is a static dataset that does not reflect the wetland changes in the past decades or capture the fill-spill dynamics. Apparently, some relatively large disjointed NWI wetlands coalesced and formed even larger wetland complexes during the extremely wet period in October 2011 when the LiDAR data were acquired. On the contrary, some small NWI wetlands appeared to have dried out without 
visible standing water. The median size of the dried NWI wetlands is approximately $1200 \mathrm{~m}^{2}$, which is considerably smaller than the median size of all NWI wetlands in this region (1780 $\mathrm{m}^{2}$ ). The decline in the number of small NWI wetlands can be partly attributed to the high sensitivity of these wetlands to hydrological and climatic changes.
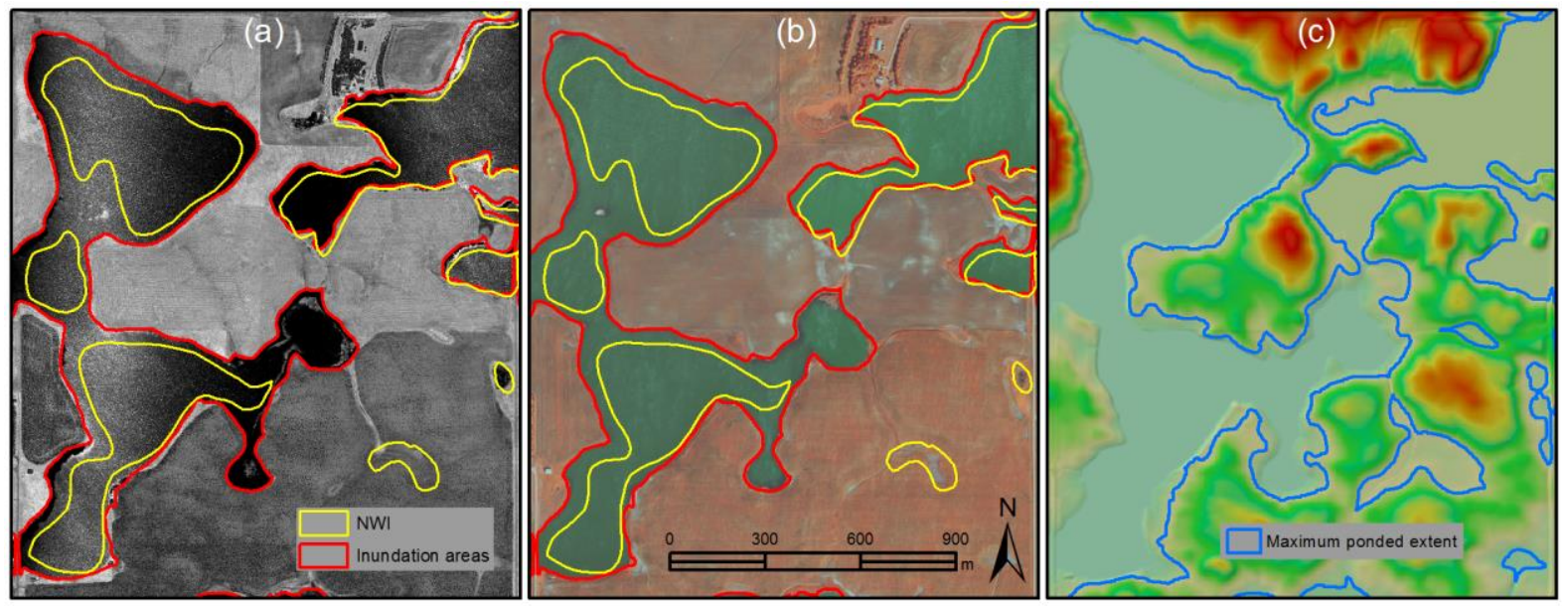

Figure 9. Comparison between inundation areas (derived from LiDAR intensity data) and NWI wetland polygons. (a) Inundation areas and NWI wetlands overlaid on LiDAR intensity image; (b) inundation areas and NWI wetlands overlaid on color infrared aerial photograph; and (c) maximum ponded extent overlaid on shaded relief of LiDAR DEM.

In addition to mapping the wetland inundation areas using LiDAR intensity imagery, the maximum potential ponded extent of wetlands can be delineated from the LiDAR DEM using the localized contour tree method (Wu et al. 2015), whereas the potential hydrologic flow pathways can be derived using the least-cost path algorithm. A small portion of the resulting map is shown in Figure 10. Clearly, the derived flow paths not only captured the permanent surface water flow paths (see the thick blue NHD flowline in Figure 10), but also the intermittent and infrequent flow paths that have not been mapped previously. By examining the flow paths overlaid on the color infrared aerial photograph (Figure 10b), it can be seen that the majority of flow paths appeared to be surrounded by vegetated areas. This indicates that flow paths are located in high soil moisture areas that are directly or indirectly related to surface water or groundwater connectivity. 

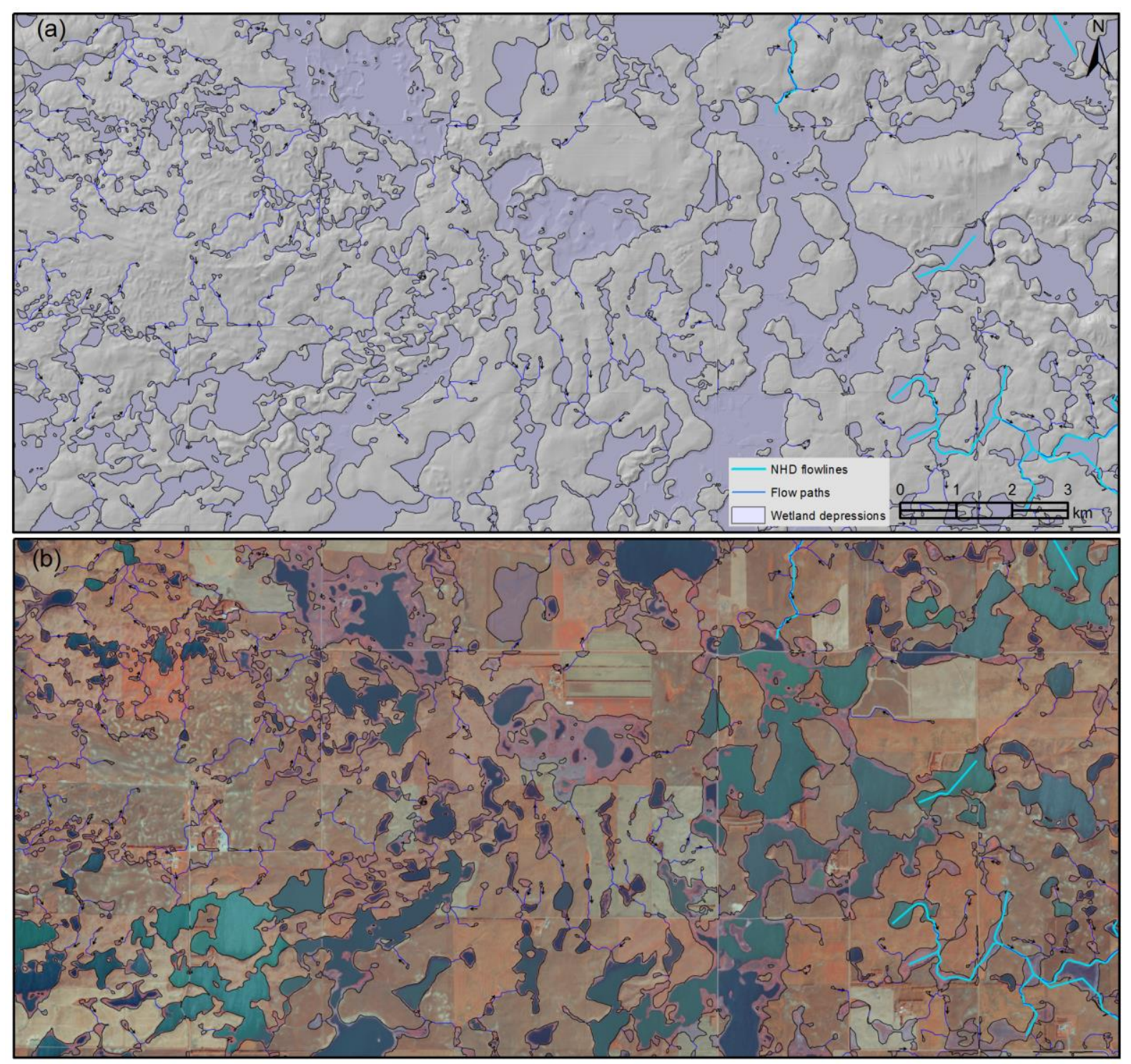

Figure 10. Examples of LiDAR-derived wetland depressions and flow paths in the Prairie Pothole Region. (a) Wetland depressions and flow paths overlaid on LiDAR shaded relief map; and (b) Wetland depressions and flow paths overlaid on color infrared aerial photograph.

It is important to note that the proposed methodology in this case study was designed to reflect the topography and hydrologic connectivity between wetlands in the Prairie Pothole Region. Assumptions have been made to simplify the complex prairie hydrology. Physicallybased hydrological models have not yet been integrated into this framework. However, filland-spill is a complex and spatially distributed hydrological process highly affected by many factors, such as surface topography, surface roughness, soil infiltration, soil properties, depression storage, precipitation, evapotranspiration, snowmelt runoff, and groundwater exchange. Nevertheless, this case study presents the first attempt to use LiDAR data for deriving nested wetland catchments and simulating flow paths at a broad-scale in the PPR.

\section{Conclusion}

Wetland mapping capabilities have been greatly improved over the past decades. Initial wetland mapping efforts were primarily based on manual photointerpretation of aerial 
photographs in conjunction with field data collection and verification, which are timeconsuming and labor-intensive. Since the first multispectral satellite data became publicly available in the 1970s, the science of wetland mapping and monitoring has been developing rapidly. The technological advances of GIS and remote sensing technologies have provided wetland mapping science with improved GIS tools and remotely sensed imagery with ever increasing spatial, temporal, and spectral resolution. In particular, recent advances in the quality and availability of high-resolution LiDAR, SAR, UAS, hyperspectral, and multispectral data, and the introduction of multi-sensor and multi-scale data fusion techniques hold great potential for improving large-scale wetland mapping and monitoring. The multitude of these geospatial datasets can provide complementary information about wetland occurrence and characteristics. More and more semi-automated and automated wetland mapping techniques and large-scale wetland inventories have become available during the past few years.

Though the use and GIS and remote sensing has resulted in improved wetland mapping capabilities, there remain many challenges that require further investigation. The challenges can be summarized in three aspects in terms of spatial, temporal, and spectral resolution of wetland inventories. First, except for North America and parts of Europe, comprehensive national-scale wetland inventories are not available for most countries. Currently available large-scale wetland inventories are inconsistent in their wetland definition, classification method, or classification system, making it difficult to conduct comparative analyses. Consequently, there is an appealing need for a universally accepted definition of wetland and wetland classification system in order to conduct a global-scale wetland inventory. In addition, the spatial resolution of most large-scale wetland inventories ranges from 250-500 $\mathrm{m}$, which might not be sufficient for fine-scale wetland mapping and management, especially for small-size temporary and ephemeral wetlands (e.g., vernal pools). Second, the temporal resolution of current large-scale wetland inventories is very limited. Most inventories are static datasets derived from one-time airborne or satellite imagery, which could not reflect seasonal or annual changes (e.g., hydroperiods, phenology) of wetlands. The increasing availability of SAR data (e.g., ESA's Sentinel-1A) holds great potential for mapping temporal changes of wetlands. Last but not least, there is a lack of spectral libraries for the large number of hydrophytic vegetation. Hyperspectral data can potentially fill the gap and provide more spectral information than other types of remote sensing imagery. However, the availability of hyperspectral data is relatively limited and the algorithms or tools for processing hyperspectral imagery are less developed compared to other data types.

\section{References}

Adam, E., Mutanga, O., \& Rugege, D. (2010). Multispectral and hyperspectral remote sensing for identification and mapping of wetland vegetation: A review. Wetlands Ecology and Management, 18, 281-296

Ameli, A.A., \& Creed, I.F. (2016). Quantifying hydrologic connectivity of wetlands to surface water systems. Hydrol. Earth Syst. Sci. Discuss., 2016, 1-28

Bengtson, M.L., Padmanabhan, G., \& Commission, N.D.S.W. (1999). A hydrologic model for assessing the influence of wetlands on flood hydrographs in the Red River Basin: Development and application. Citeseer 
Blaschke, T. (2010). Object based image analysis for remote sensing. ISPRS Journal of Photogrammetry and Remote Sensing, 65, 2-16

Brian, B. (2015). Mapping and Monitoring Surface Water and Wetlands with Synthetic Aperture Radar. In M.W. Lang, L.L. Bourgeau-Chavez, R.W. Tiner, \& V.V. Klemas (Eds.), Remote Sensing of Wetlands: Applications and Advances (pp. 119-136): CRC Press

Burne, M.R. (2001). Massachusetts aerial photo survey of potential vernal pools. Natural Heritage \& Endangered Species Program

Burton, T.M., \& Tiner, R.W. (2009). Ecology of Wetlands. Encyclopedia of Inland Waters (pp. 507-515). Oxford: Academic Press

Channan, S., Collins, K., \& Emanuel, W. (2014). Global mosaics of the standard MODIS land cover type data. University of Maryland and the Pacific Northwest National Laboratory, College Park, Maryland, USA, 30

Chu, X. (2015). Delineation of Pothole-Dominated Wetlands and Modeling of Their Threshold Behaviors. Journal of Hydrologic Engineering, D5015003

Cohen, M.J., Creed, I.F., Alexander, L., Basu, N.B., Calhoun, A.J., Craft, C., D’Amico, E., DeKeyser, E., Fowler, L., \& Golden, H.E. (2016). Do geographically isolated wetlands influence landscape functions? Proceedings of the National Academy of Sciences, 113, 1978-1986

Cowardin, L.M., Carter, V., Golet, F.C., \& LaRoe, E.T. (1979). Classification of wetlands and deepwater habitats of the United States. US Fish and Wildlife Service FWS/OBS, 79, 131

Dahl, T.E. (1990). Wetlands losses in the United States, 1780's to 1980's. Report to the Congress. In (p. 13): U.S. Department of the Interior, Fish and Wildlife Service, Washington, D.C

Dahl, T.E. (2014). Status and trends of prairie wetlands in the United States 1997 to 2009. In (p. 67): U.S. Department of the Interior, Fish and Wildlife Service, Ecological Services, Washington, D.C.

Duda, T., \& Canty, M. (2002). Unsupervised classification of satellite imagery: Choosing a good algorithm. International Journal of Remote Sensing, 23, 2193-2212

Dugan, P. (1993). Wetland in danger: a world conservation atlas. In: Oxford: Oxford University Press

Enwright, N., Forbes, M.G., Doyle, R.D., Hunter, B., \& Forbes, W. (2011). Using Geographic Information Systems (GIS) to Inventory Coastal Prairie Wetlands Along the Upper Gulf Coast, Texas. Wetlands, 31, 687-697

Erwin, K.L. (2009). Wetlands and global climate change: the role of wetland restoration in a changing world. Wetlands Ecology and Management, 17, 71

Feng, M., Sexton, J.O., Channan, S., \& Townshend, J.R. (2016). A global, high-resolution (30m) inland water body dataset for 2000: First results of a topographic-spectral classification algorithm. International Journal of Digital Earth, 9, 113-133

Finlayson, C., Davidson, N., Spiers, A., \& Stevenson, N. (1999). Global wetland inventorycurrent status and future priorities. Marine and Freshwater Research, 50, 717-727 
Fluet-Chouinard, E., Lehner, B., Rebelo, L.-M., Papa, F., \& Hamilton, S.K. (2015). Development of a global inundation map at high spatial resolution from topographic downscaling of coarse-scale remote sensing data. Remote Sensing of Environment, 158, 348-361

Gleason, R.A., Laubhan, M.K., Tangen, B.A., \& Kermes, K.E. (2008). Ecosystem services derived from wetland conservation practices in the United States Prairie Pothole Region with an emphasis on the US Department of Agriculture Conservation Reserve and Wetlands Reserve Programs

Gleason, R.A., Tangen, B.A., Laubhan, M.K., Kermes, K.E., \& Euliss Jr, N.H. (2007). Estimating water storage capacity of existing and potentially restorable wetland depressions in a subbasin of the Red River of the North. In (p. 36): U.S. Geological Survey Open-File Report 2007-1159.

Gumbricht, T. (2012). Mapping global tropical wetlands from earth observing satellite imagery. Bogor, Indonesia: Center for International Forestry Research (CIFOR)

Hayashi, M., van der Kamp, G., \& Rosenberry, D.O. (2016). Hydrology of Prairie Wetlands: Understanding the Integrated Surface-Water and Groundwater Processes. Wetlands, 1-18

Huang, S., Dahal, D., Young, C., Chander, G., \& Liu, S. (2011a). Integration of Palmer Drought Severity Index and remote sensing data to simulate wetland water surface from 1910 to 2009 in Cottonwood Lake area, North Dakota. Remote Sensing of Environment, $115,3377-3389$

Huang, S., Young, C., Feng, M., Heidemann, K., Cushing, M., Mushet, D.M., \& Liu, S. (2011b). Demonstration of a conceptual model for using LiDAR to improve the estimation of floodwater mitigation potential of Prairie Pothole Region wetlands. Journal of Hydrology, 405, 417-426

Hubbard, D.E., \& Linder, R.L. (1986). Spring runoff retention in prairie pothole wetlands. Journal of Soil \& Water Conservation, 41, 122-125

Johnston, C.A. (2013). Wetland losses due to row crop expansion in the Dakota Prairie Pothole Region. Wetlands, 33, 175-182

Joseph, F.K., Jennifer, M.C., Lian, P.R., \& Keith, C.P. (2015). Theory and Applications of Object-Based Image Analysis and Emerging Methods in Wetland Mapping. In R.W. Tiner, M.W. Lang, \& V.V. Klemas (Eds.), Remote Sensing of Wetlands: Applications and Advances (pp. 175-194): CRC Press

Keddy, P.A. (2010). Wetland ecology: principles and conservation. Cambridge University Press

Klemas, V. (2011). Remote sensing of wetlands: case studies comparing practical techniques. Journal of Coastal Research, 27, 418-427

Lane, C., Liu, H., Autrey, B., Anenkhonov, O., Chepinoga, V., \& Wu, Q. (2014). Improved Wetland Classification Using Eight-Band High Resolution Satellite Imagery and a Hybrid Approach. Remote Sensing, 6, 12187-12216

Lane, C.R., \& D'Amico, E. (2016). Identification of Putative Geographically Isolated Wetlands of the Conterminous United States. JAWRA Journal of the American Water Resources Association, n/a-n/a 
Lang, M., \& McCarty, G. (2009). Lidar intensity for improved detection of inundation below the forest canopy. Wetlands, 29, 1166-1178

Lang, M., McCarty, G., Oesterling, R., \& Yeo, I.-Y. (2013). Topographic Metrics for Improved Mapping of Forested Wetlands. Wetlands, 33, 141-155

Lang, M.W., Bourgeau-Chavez, L.L., Tiner, R.W., \& Klemas, V.V. (2015). Advances in Remotely Sensed Data and Techniques for Wetland Mapping and Monitoring. In R.W. Tiner, M.W. Lang, \& V.V. Klemas (Eds.), Remote Sensing of Wetlands: Applications and Advances (pp. 79-116): CRC Press

Lehner, B., \& Döll, P. (2004). Development and validation of a global database of lakes, reservoirs and wetlands. Journal of Hydrology, 296, 1-22

Leibowitz, S.G., Mushet, D.M., \& Newton, W.E. (2016). Intermittent Surface Water Connectivity: Fill and Spill Vs. Fill and Merge Dynamics. Wetlands, 1-20

Lindsay, J.B. (2016). Whitebox GAT: A case study in geomorphometric analysis. Computers \& Geosciences, 95, 75-84

Liu, H., Wang, L., Sherman, D., Gao, Y., \& Wu, Q. (2010). An object-based conceptual framework and computational method for representing and analyzing coastal morphological changes. International Journal of Geographical Information Science, 24, 1015-1041

Lyon, J.G., Lopez, R.D., Lyon, L.K., \& Lopez, D.K. (2001). Wetland landscape characterization: GIS, remote sensing and image analysis. CRC Press

McCauley, L., \& Anteau, M. (2014). Generating Nested Wetland Catchments with ReadilyAvailable Digital Elevation Data May Improve Evaluations of Land-Use Change on Wetlands. Wetlands, 1-10

McFeeters, S.K. (1996). The use of the Normalized Difference Water Index (NDWI) in the delineation of open water features. International Journal of Remote Sensing, 17, 14251432

Melton, J., Wania, R., Hodson, E., Poulter, B., Ringeval, B., Spahni, R., Bohn, T., Avis, C., Beerling, D., \& Chen, G. (2013). Present state of global wetland extent and wetland methane modelling: conclusions from a model intercomparison project (WETCHIMP). Biogeosciences, 10, 753-788

Miller, M.W., \& Nudds, T.D. (1996). Prairie landscape change and flooding in the Mississippi River Valley. Conservation Biology, 10, 847-853

Minke, A.G.N. (2009). Estimating water storage of prairie pothole wetlands. In: University of Saskatchewan

Mitsch, W.J., \& Gosselink, J.G. (2000). The value of wetlands: importance of scale and landscape setting. Ecological Economics, 35, 25-33

National Wetlands Working Group (1997). The Canadian Wetland Classification System, 2nd Edition. Warner, B.G. and C.D.A. Rubec (eds.). In (p. 68): Wetlands Research Branch, University of Waterloo

Niu, Z., Zhang, H., Wang, X., Yao, W., Zhou, D., Zhao, K., Zhao, H., Li, N., Huang, H., Li, C., Yang, J., Liu, C., Liu, S., Wang, L., Li, Z., Yang, Z., Qiao, F., Zheng, Y., Chen, Y., Sheng, Y., Gao, X., Zhu, W., Wang, W., Wang, H., Weng, Y., Zhuang, D., Liu, J., Luo, 
Z., Cheng, X., Guo, Z., \& Gong, P. (2012). Mapping wetland changes in China between 1978 and 2008. Chinese Science Bulletin, 57, 2813-2823

Oslund, F.T., Johnson, R.R., \& Hertel, D.R. (2010). Assessing Wetland Changes in the Prairie Pothole Region of Minnesota From 1980 to 2007. Journal of Fish and Wildlife Management, 1, 131-135

Ozesmi, S.L., \& Bauer, M.E. (2002). Satellite remote sensing of wetlands. Wetlands Ecology and Management, 10, 381-402

Ramsar Convention (2009). Wetlands: a global disappearing act.

Ramsar Convention (2016). Ramsar Sites Information Service. Available online: https://rsis.ramsar.org/ (accessed on November 21, 2016)

Ramsar Convention Secretariat (2016). An Introduction to the Ramsar Convention on Wetlands, 7th ed. (previously The Ramsar Convention Manual). In. Gland, Switzerland

Rebelo, L.M., Finlayson, C.M., \& Nagabhatla, N. (2009). Remote sensing and GIS for wetland inventory, mapping and change analysis. Journal of Environmental Management, 90, 2144-2153

Rover, J., \& Mushet, D.M. (2015). Mapping Wetlands and Surface Water in the Prairie Pothole Region of North America. In R.W. Tiner, M.W. Lang, \& V.V. Klemas (Eds.), Remote Sensing of Wetlands: Applications and Advances (pp. 347-368): CRC Press

Sader, S.A., Ahl, D., \& Liou, W.S. (1995). Accuracy of landsat-TM and GIS rule-based methods for forest wetland classification in Maine. Remote Sensing of Environment, 53, 133-144

Sayre, R., Dangermond, J., Frye, C., Vaughan, R., Aniello, P., Breyer, S., Cribbs, D., Hopkins, D., Nauman, R., \& Derrenbacher, W. (2014). A new map of global ecological land units - an ecophysiographic stratification approach. Washington, DC: Association of American Geographers

Sloan, C.E. (1972). Ground-water hydrology of prairie potholes in North Dakota. U.S. Government Printing Office Washington, D.C., USA

Sörensen, R., Zinko, U., \& Seibert, J. (2006). On the calculation of the topographic wetness index: evaluation of different methods based on field observations. Hydrology and Earth System Sciences Discussions, 10, 101-112

Steen, V., Skagen, S.K., \& Noon, B.R. (2014). Vulnerability of Breeding Waterbirds to Climate Change in the Prairie Pothole Region, U.S.A. PLoS ONE, 9, e96747

Tiner, R.W. (1991). The Concept of a Hydrophyte for Wetland Identification. BioScience, 41, 236-247

Tiner, R.W. (1997). NWI maps: what they tell us. National Wetlands Newsletter, 19, 7-12

Tiner, R.W. (2009a). Ecology of Wetlands: Classification Systems Encyclopedia of Inland Waters (pp. 516-525). Oxford: Academic Press

Tiner, R.W. (2009b). Global Distribution of Wetlands. Encyclopedia of Inland Waters (pp. 526-530). Oxford: Academic Press

Tiner, R.W. (2009c). Status report for the National Wetlands Inventory program: 2009. US Department of the Interior, Fish and Wildlife Service, Division of Habitat and Resource Conservation, Branch of Resource and Mapping Support, Arlington 
Tiner, R.W. (2015a). Classification of Wetland Types for Mapping and Large-Scale Inventories. In R.W. Tiner, M.W. Lang, \& V.V. Klemas (Eds.), Remote Sensing of Wetlands: Applications and Advances (pp. 19-42): CRC Press

Tiner, R.W. (2015b). Wetlands: An Overview. In R.W. Tiner, M.W. Lang, \& V.V. Klemas (Eds.), Remote Sensing of Wetlands: Applications and Advances (pp. 3-18): CRC Press

Todhunter, P.E., \& Rundquist, B.C. (2004). Terminal lake flooding and wetland expansion in Nelson County, North Dakota. Physical Geography, 25, 68-85

Trimble (2016). eCognition Developer 9. Available online: http://www.ecognition.com/ (accessed on November 21, 2016)

Tucker, C.J. (1979). Red and photographic infrared linear combinations for monitoring vegetation. Remote Sensing of Environment, 8, 127-150

USDA-NRCS (2010). Field indicators of hydric soils in the United States. In L. Vasilas, G. Hurt, \& C. Noble (Eds.), United States Department of Agriculture, Natural Resources Conservation Service, in cooperation with the National Technical Committee for Hydric Soils, Washington, DC

USDA-NRCS (2016a). National List of Hydric Soils. Available online: https://www.nrcs.usda.gov/wps/portal/nrcs/main/soils/use/hydric/ (accessed on November 17, 2016)

USDA-NRCS (2016b). Web Soil Survey (WSS). Available online: http://websoilsurvey.nrcs.usda.gov/ (accessed on November 17, 2016)

USDA (2016). Geospatial Data Gateway. Available online: https://gdg.sc.egov.usda.gov/ (accessed on November 19, 2016)

USFWS (2016). NWI Wetlands Mapper. Available online: https://www.fws.gov/wetlands/Data/Mapper.html (accessed on November 21, 2016) van der Kamp, G., Hayashi, M., Bedard-Haughn, A., \& Pennock, D. (2016). Prairie Pothole Wetlands - Suggestions for Practical and Objective Definitions and Terminology. Wetlands, 1-7

Vanderhoof, M., Alexander, L., \& Todd, M.J. (2016). Temporal and spatial patterns of wetland extent influence variability of surface water connectivity in the Prairie Pothole Region, United States. Landscape Ecology, 31, 805-824

Winter, T. (1989). Hydrologic studies of wetlands in the northern prairie. In A.G. Van Der Valk (Ed.), Northern Prairie Wetlands. Ames, IA: Iowa-State University Press

Wu, Q., Lane, C., \& Liu, H. (2014). An Effective Method for Detecting Potential Woodland Vernal Pools Using High-Resolution LiDAR Data and Aerial Imagery. Remote Sensing, 6, 11444-11467

Wu, Q., \& Lane, C.R. (2016). Delineation and Quantification of Wetland Depressions in the Prairie Pothole Region of North Dakota. Wetlands, 36, 215-227

Wu, Q., \& Lane, C.R. (2017). Delineating wetland catchments and modeling hydrologic connectivity using LiDAR data and aerial imagery. Hydrol. Earth Syst. Sci. Discuss., $2017,1-32$

Wu, Q., Liu, H., Wang, S., Yu, B., Beck, R., \& Hinkel, K. (2015). A localized contour tree method for deriving geometric and topological properties of complex surface depressions 
based on high-resolution topographical data. International Journal of Geographical Information Science, 29, 2041-2060

Zedler, J.B., \& Kercher, S. (2005). WETLAND RESOURCES: Status, Trends, Ecosystem Services, and Restorability. Annual Review of Environment and Resources, 30, 39-74

Zhang, B., Schwartz, F.W., \& Liu, G. (2009). Systematics in the size structure of prairie pothole lakes through drought and deluge. Water Resources Research, 45

Zheng, Y., Niu, Z., Gong, P., \& Wang, J. (2015). A database of global wetland validation samples for wetland mapping. Science Bulletin, 60, 428-434

\section{Relevant Websites}

CIFOR Global Wetlands: http://www.cifor.org/global-wetlands

ESA CCI Global Land Cover Dataset: http://www.esa-landcover-cci.org/

Free GIS Data: http://freegisdata.rtwilson.com/

Global Ecological Land Units (ELUs): http://esriurl.com/eco/

Global GIS Datasets: http://www.edenextdata.com/?q=content/global-gis-datasets-links-0

Global Lakes and Wetlands Database (GLWD): http://www.worldwildlife.org/

Global Land Cover Facility: http://www.landcover.org/

Ramsar Sites Information Service: https://rsis.ramsar.org

U.S. Fish \& Wildlife Services National Wetlands Inventory: https://www.fws.gov/wetlands/ USDA-NRCS SSURGO Database: http://websoilsurvey.nrcs.usda.gov/ 